\title{
Socio- Economic Characteristic of Goat Keepers in Marwar Region of Rajasthan State, India
}

\author{
Shripal Siyak $^{1 *}$, M. L. Gurjar ${ }^{1}$, M. C. Sharma ${ }^{1}$, Rohitash Kumar ${ }^{2}$ \\ and Dushyant Dev Bhal $^{3}$ \\ ${ }^{1}$ Department of Livestock Production Management, ${ }^{2}$ Department of Vety. \& A.H. Extension \\ Education, ${ }^{3}$ Department of Veterinary Pathology, \\ CVAS, Navania, Vallabhnagar, Udaipur (Rajasthan)-313601, India \\ *Corresponding author
}

A B S T R A C T

\begin{tabular}{|l|}
\hline Key w o r d s \\
Goat owners, Age, \\
$\begin{array}{l}\text { Education, Socio } \\
\text { economic profile, } \\
\text { Marwar region }\end{array}$ \\
\hline Article Info \\
\hline $\begin{array}{l}\text { Accepted: } \\
\text { 20 May } 2020 \\
\text { Available Online: } \\
\text { 10 June } 2020\end{array}$ \\
\hline
\end{tabular}

The present study was conducted in Marwar region of Rajasthan selected purposely keeping in view the fact that the region has highest goat population. The present study was conducted in Jodhpur, Nagaur and Pali districts selected purposely keeping in view the fact that the district has highest goat population of Marwar region of South-Western Rajasthan. One tehsil was selected from each districts viz. Bilara from Jodhpur, Nagaur from Nagaur and Sojat from Pali Districts were randomly selected. To meet the required sample size from each tehsil, four villages were selected from each tehsils. Thus, total twelve villages were selected for the present study. Therefore 15 respondents were randomly selected from each selected villages. The total sample size for this study was 180 goat keepers. The study revealed that majority of goat owners were had that the majority $(65.55 \%)$ of the total respondents were middle age group followed by young 19.45 per cent and old age group15.00 per cent It was observed that majority of the respondents education level were illiterate (63.89\%), respondents had large size families $(41.11 \%)$, living joint type family $(81.67 \%)$, male headed goat owners $(96.67 \%)$ and small land holders $(65 \%)$. The maximum goat owners of the study area from OBC $(56.11 \%)$. showed that majority $(51.67 \%)$ of the respondents had low level of income while 37.22 per cent had medium level of income and remaining 11.11 per cent respondents had high level of income from goats rearing practices in the study area.

\section{Introduction}

Livestock play a vital role in the agricultural and rural economics of the developing Countries. Not only they produce food directly, but they also provide key inputs to crop agriculture. Goats have been associated with man since dawn of agriculture and domestication of animals, making them socioeconomically, a very important animal providing products (meat, milk, fibre, hair ) and service to man throughout the world, especially in the developing countries.

In India, the total numbers of goat breeds that have been recognized till date is 34 and most other still remain unexplored (ICARNBAGR). According to 20th livestock census, the goat population has increased by 10.14 per cent from the previous census 
(2012). But in Rajasthan state a decline in goat population 3.81 per cent- suggesting the need of sustainable management for preserving goat breeds and population. Livestock in developing countries like India have a considerable role in its rural area population as it provides labour for land cultivation and employment to huge number of people. India is contributing 11.6 per cent of total livestock in world and 27.8 per cent of which is contributed by goats. The maximum goat milk producing state in India is Uttar Pradesh followed by Rajasthan, (Basic Animal Husbandry and Fisheries Statistics, 2014). Good quality milk is produced by Indian goat breeds such as Jamunapari, Barbari, Beetle, Surti and Jakhrana. As per $20^{\text {th }}$ Livestock census, and BAHS (2014) India's livestock sector is one of the largest in the world having huge livestock population of 535.78 million. According to recent census by Govt. of India in 2012 the Goat population is 148.88 million in India. In Rajasthan the total population is 20.84 million. Total meat production including goat meat was 5.9 million Tone in 2012-13 as compared to 1.9 million tons in 2001-02. (AHD, 2019)

In Rajasthan state goat farming has become an income generating activity for every class of society whether they are landless or land holder, resource poor or progressive farmer and irrespective of their occupation. Hence, with this background the present study was conducted to know the personal socio economic characteristics of goat keepers of Marwar region of Rajasthan.

\section{Materials and Methods}

Marwar region of Rajasthan comprises of five districts, viz. Jodhpur, Jalore, Nagaur, Pali and Barmer districts of Rajasthan. The present study was conducted in Jodhpur, Nagaur and Pali districts selected purposely keeping in view the fact that the district has highest goat population of Marwar region of SouthWestern Rajasthan. One tehsil was selected from each districts viz. Bilara from Jodhpur, Nagaur from Nagaur and Sojat from Pali Districts were randomly selected. To meet the required sample size from each tehsil, four villages were selected from each tehsils. Thus, total twelve villages were selected for the present study. Therefore 15 respondents were randomly selected from each selected villages. The total sample size for this study was 180 goat keepers.

The data were collected with the help of pretested structured interview schedule by holding personal interview with goat keepers by the researcher.

\section{Results and Discussion}

The results of data regarding personal characteristics viz., age, sex, education, size of family and type of family of the respondents. The results have been presented in following subsequent tables.

\section{General profile of goat owners}

\section{Personal characteristics of the goat owners}

In this section, data regarding general profile viz., age, sex, education, size of family and type of family, size of land holding, main occupation, flock size and income from goat rearing of the respondents have been presented. The results have been presented in subsequent tables.

\section{Age of respondents}

On the basis of their age, the respondents were classified into three categories i.e., young (<35years), middle (35-57 years) and old ( $>57$ years). The data presented in table-1 depicts that the majority $(65.55 \%)$ of the total respondents were middle age group followed 
by young 19.45 per cent and old age group15.00 per cent in the study area. The average age of total respondents was around $45.53 \pm 0.81$ in study area. Pali district had more goat owners in middle age is associated with less involvement of old farmers as compared to Jodhpur and Nagaur districts.

The findings are in agreement with Bhatiya $e t$ al., (2005) and Sorathiya et al., (2016), Kumar R. (2017) whereas, contradictory with the study by Sharma (2005), Tanwar et al., (2008),Mishra et al., (2012), Koli and Koli (2016),Nipane et al., (2016), Mordia, A. (2017) and Gameti, R.K. (2018)

\section{Sex of respondents}

On the basis of sex, the total respondents were classified into two categories viz, male and female.

Table-2 indicates that out of total respondents, majority $(96.67 \%)$ of the respondents were male while as only 3.33 per cent respondents were female. The results indicate that a lot of concrete effort would be required to bring rural women entrepreneur in goat husbandry enterprise on if it is suppose that women can rearers' goat entry. These observations are in agreement of Nipane et al., (2016), Mordia, A. (2017) and Gameti, R.K. (2018).

\section{Education level of respondents}

The table-3 indicates that the level of education of selected respondents, were classified into three categories, viz, illiterate, up to primary level and above primary level. It was observed that the majority $(63.89 \%)$ of total respondents were illiterate followed by up to primary level 28.33 per cent and above primary level 7.78 per cent. In present study we observed that the majority $(63.89 \%)$ of the respondents were illiterate.

These results are in agreement with the findings of Tanwar et al., (2008), Singh and Rai (2006), Mishra et al., (2012), Koli and Koli (2016), Mordia, A. (2017) and Gameti R.K.(2018).

\section{Family size of respondents}

On the basis of number of members in the family, the respondents were classified into three categories viz., small family (up to 4 members), medium family (4-8 members) and large family (above 8 members). The data in table-4 indicates that average family size was $8.34 \pm 0.25$ members.

The study revealed that the majority of respondents $(41.11 \%)$ were living in large size of family (>8 members) followed by 40.56 per cent respondents were have medium size of family whereas 18.33 per cent respondents were have small size of family. These results are in agreement with the findings of Tanwar et al., (2007), Tanwar et al., (2008), Mishra et al., (2012), Koli and Koli (2016), Kumar R. (2017) and Gameti, R.K(2018).

\section{Type of family}

On the basis of type of family, the total respondents were classified into two categories viz., joint family and nuclear family. The data presented in table- 5 indicates that out of total respondents, majority (81.67\%) of the respondents belongs to the joint family, while as 18.33 per cent had nuclear family in the study sample. These results are in agreement with the findings of Patil et al., (2012), Mishra et al., (2012), Islam (2018) and Mordia, A. (2017).

\section{Land holding}

On the basis of size of land holding, the total respondents were classified into three categories viz., small (up to 1ha.), medium (12 ha.) and large (above 2 ha.). Their 
frequencies were counted and converted into percentage for all the categories of respondents. The data in table- 6 indicate that, average land holding was $2.97 \pm 0.21 \mathrm{ha}$.

The majority of the total respondents (65\%) had small size of land holding. 18.33 per cent had medium size of land holding and remaining 16.67 per cent respondents had large size of land holding in study area. Most of the goat owners were poor and had no ancestral land assets.

These results are close to the findings of Singh and Rai (2006), Tanwar et al., (2008), Mordia, A. (2017) and Gameti, (2018).

\section{Main occupation}

On the basis of type of main occupation, the respondents were classified into three categories viz. Animal husbandry, Animal husbandry + Agriculture and Animal husbandry + Agriculture + others. Their frequencies were counted and converted into percentage for all the categories of respondents.

The results presented in table-7 showed that 36.11 per cent total respondents of all district had Animal husbandry while 32.78 per cent of total respondent were dependent on Animal husbandry + Agriculture and rest 31.11 per cent respondents were had Animal husbandry + Agriculture + others as their main occupation for their livelihood. These results are close to the findings of Sharma (2005) and Nipane et al., (2016) Sabapara (2016) et al.,

\section{Flock size}

On the basis of number of goats in the flock, the respondents were classified into three categories viz., small flock $(<15)$, medium flock (15-30) and large flock (above 30) goats. Their frequencies were counted and converted into percentage for all the categories of respondents.

The data recorded in table- 8 shows that the average flock size was $29.46 \pm 1.68$.Majority of respondents $(36.67 \%)$ had large flock size of more than 30 goats followed by small flock size $(35 \%)$ less than 15 goats and medium sized flock (28.33\%). These findings contradict with the observation of Sharma (2005), Sharma et al., (2007), Jayashree et al., (2014), Gebreyesus et al., (2014), Mordia, A. (2017) and Gameti R.K.(2018).

\section{Distribution of respondents on the basis of cast}

The results presented in table- 9 indicates that the cast of selected classified into five categories i.e., SC, ST, SBC, $\mathrm{OBC}$ and General. There frequency was counted and converted into percentage for all the categories of respondents.

The data recorded in table showed the majority of respondents were from OBC 56.11 percent whereas 23.88 percent from SBC. While 11.67 percent respondents were from SC, and 6.11 percent respondents were from General and rest of 2.22 percent from ST. the similar finding were observed by Sabapara (2016) et al.,

\section{Income from goat rearing}

On the basis of income from goat rearing, the respondents were classified into three categories i.e., low level of income $\left(<30000^{\circ}\right)$, medium income (30000-60000') and high income $\left(>60000^{\circ}\right) \quad ₹ / A n n u m$. Their frequencies were counted and converted into percentage for all the categories of respondents. 
Table.1 Distribution of respondents on the basis of age $(n=180)$

\begin{tabular}{|c|c|c|c|c|c|c|c|c|c|}
\hline \multirow{2}{*}{$\begin{array}{c}\text { S. } \\
\text { No. }\end{array}$} & \multirow[t]{2}{*}{ Age Category } & \multicolumn{2}{|c|}{ Jodhpur } & \multicolumn{2}{|c|}{ Nagaur } & \multicolumn{2}{|c|}{ Pali } & \multicolumn{2}{|c|}{ Total } \\
\hline & & $\mathbf{F}$ & $\%$ & $\mathbf{F}$ & $\%$ & $\mathbf{F}$ & $\%$ & $\mathbf{F}$ & $\%$ \\
\hline 1 & Young (<35 Years) & 14 & 23.33 & 13 & 21.67 & 8 & 13.33 & 35 & 19.45 \\
\hline 2 & Middle (35-57 Years) & 38 & 63.34 & 36 & 60.00 & 43 & 71.67 & 118 & 65.55 \\
\hline \multirow[t]{3}{*}{3} & Old ( $>57$ years) & 8 & 13.33 & 11 & 18.33 & 9 & 15.00 & 27 & 15.00 \\
\hline & Total & 60 & 100 & 60 & 100 & 60 & 100 & 180 & 100 \\
\hline & Mean \pm SE & \multicolumn{2}{|c|}{$45.05 \pm 1.34$} & \multicolumn{2}{|c|}{$44.85 \pm 1.45$} & \multicolumn{2}{|c|}{$46.71 \pm 1.42$} & \multicolumn{2}{|c|}{$45.53 \pm 0.81$} \\
\hline
\end{tabular}

$\mathrm{F}=$ frequency, $\%=$ per cent

Table.2 Distribution of respondents on the basis of sex $(n=180)$

\begin{tabular}{|c|c|c|c|c|c|c|c|c|c|}
\hline S.No & \multirow{2}{*}{ Sex } & \multicolumn{2}{|c|}{ Jodhpur } & \multicolumn{2}{c|}{ Nagaur } & \multicolumn{2}{c|}{ Pali } & \multicolumn{2}{c|}{ Total } \\
\cline { 3 - 11 } & & F & \% & F & \% & F & \% & F & \% \\
\hline 1 & Male & 58 & 96.67 & 57 & 95.00 & 59 & 98.33 & 174 & 96.67 \\
\hline 2 & Female & 02 & 3.33 & 03 & 05.00 & 01 & 1.67 & 06 & 03.33 \\
\hline & Total & 60 & 100 & 60 & 100 & 60 & 100 & 180 & 100 \\
\hline
\end{tabular}

$\mathrm{F}=$ frequency, $\%=$ per cent

Table.3 Distribution of respondents on the basis of level of education $(n=180)$

\begin{tabular}{|c|c|c|c|c|c|c|c|c|c|}
\hline \multirow{2}{*}{ S.No. } & Education & \multicolumn{2}{|c|}{ Jodhpur } & \multicolumn{2}{c|}{ Nagaur } & \multicolumn{2}{c|}{ Pali } & \multicolumn{2}{c|}{ Total } \\
\cline { 2 - 10 } & F & \% & F & \% & F & \% & F & \% \\
\hline 1 & Illiterate & 30 & 50.00 & 33 & 55.00 & 52 & 86.67 & 115 & 63.89 \\
\hline 2 & Upto primary level & 22 & 36.67 & 22 & 36.67 & 07 & 11.67 & 51 & 28.33 \\
\hline 3 & Above primary level & 08 & 13.33 & 05 & 8.33 & 01 & 1.66 & 14 & 7.78 \\
\hline & Total & 60 & 100 & 60 & 100 & 60 & 100 & 180 & 100 \\
\hline
\end{tabular}

$\mathrm{F}=$ frequency, $\%=$ per cent

Table.4 Distribution of respondents on the basis of size of family $(n=180)$

\begin{tabular}{|c|c|c|c|c|c|c|c|c|c|}
\hline S.No. & Age Category & \multicolumn{2}{|c|}{ Jodhpur } & \multicolumn{2}{c|}{ Nagaur } & \multicolumn{2}{|c|}{ Pali } & \multicolumn{2}{c|}{ Total } \\
\cline { 2 - 10 } & & F & $\mathbf{\%}$ & F & $\%$ & F & $\%$ & F & $\%$ \\
\hline 1 & Small (Upto 4 members) & 10 & 16.67 & 12 & 20.00 & 11 & 18.33 & 33 & 18.33 \\
\hline 2 & Medium (4-8 members) & 22 & 36.66 & 18 & 30.00 & 33 & 55.00 & 73 & 40.56 \\
\hline 3 & Large (>8 members) & 28 & 46.67 & 30 & 50.00 & 16 & 23.67 & 74 & 41.11 \\
\hline & Total & 60 & 100 & 60 & 100 & 60 & 100 & 180 & 100 \\
\hline & Mean \pm SE & $8.93 \pm 0.51$ & $8.43 \pm 0.41$ & $7.66 \pm 0.37$ & $8.34 \pm 0.25$ \\
\hline
\end{tabular}

$\mathrm{F}=$ frequency, $\%=$ per cent 
Table.5 Distribution of respondents on the basis of type of family $(n=180)$

\begin{tabular}{|c|c|c|c|c|c|c|c|c|c|}
\hline \multirow{2}{*}{ S. } & Type of family & \multicolumn{2}{|c|}{ Jodhpur } & \multicolumn{2}{c|}{ Nagaur } & \multicolumn{2}{c|}{ Pali } & \multicolumn{2}{c|}{ Total } \\
\cline { 2 - 10 } No. & & F & $\mathbf{\%}$ & F & $\mathbf{\%}$ & F & \% & F & $\%$ \\
\hline $\mathbf{1}$ & Joint & 50 & 83.33 & 48 & 80.00 & 49 & 81.67 & 147 & 81.67 \\
\hline $\mathbf{2}$ & Nuclear & 10 & 16.67 & 12 & 20.00 & 11 & 18.33 & 33 & 18.33 \\
\hline & Total & 60 & 100 & 60 & 100 & 60 & 100 & 180 & 100 \\
\hline
\end{tabular}

$\mathrm{F}=$ frequency, $\%=$ per cent

Table.6 Distribution of respondents on the basis of land holding $(n=180)$

\begin{tabular}{|c|c|c|c|c|c|c|c|c|c|}
\hline \multirow{2}{*}{$\begin{array}{l}\text { S. } \\
\text { No. }\end{array}$} & \multirow[t]{2}{*}{ Land holding } & \multicolumn{2}{|c|}{ Jodhpur } & \multicolumn{2}{|c|}{ Nagaur } & \multicolumn{2}{|c|}{ Pali } & \multicolumn{2}{|c|}{ Total } \\
\hline & & $\mathbf{F}$ & $\%$ & $\mathbf{F}$ & $\%$ & $\mathbf{F}$ & $\%$ & $\mathbf{F}$ & $\%$ \\
\hline 1 & Small (< 1 ha.) & 28 & 66.67 & 35 & 56.67 & 55 & 91.67 & 117 & 65.00 \\
\hline 2 & Medium (1-2 ha.) & 14 & 23.33 & 15 & 25.00 & 04 & 6.67 & 33 & 18.33 \\
\hline \multirow[t]{3}{*}{3} & Large (>2 ha.) & 18 & 30.00 & 11 & 18.33 & 01 & 1.66 & 30 & 16.67 \\
\hline & Total & 60 & 100 & 60 & 100 & 60 & 100 & 180 & 100 \\
\hline & Mean \pm SE & \multicolumn{2}{|c|}{$4.21 \pm 0.40$} & \multicolumn{2}{|c|}{$3.18 \pm 0.39$} & \multicolumn{2}{|c|}{$1.45 \pm 0.13$} & \multicolumn{2}{|c|}{$2.97 \pm 0.21$} \\
\hline
\end{tabular}

$\mathrm{F}=$ frequency, $\%=$ per cent

Table.7 Distribution of respondents on the basis of main occupation $(n=180)$

\begin{tabular}{|c|c|c|c|c|c|c|c|c|c|}
\hline S.No. & Occupation & \multicolumn{2}{|c|}{ Jodhpur } & \multicolumn{2}{|c|}{ Nagaur } & \multicolumn{3}{|c|}{ Pali } & \multicolumn{2}{c|}{ Total } \\
\cline { 2 - 10 } & F & $\mathbf{\%}$ & $\mathbf{F}$ & $\mathbf{\%}$ & $\mathbf{F}$ & $\mathbf{\%}$ & F & $\%$ \\
\hline $\mathbf{1}$ & Animal husbandry & 13 & 21.67 & 18 & 30.00 & 34 & 56.67 & 65 & 36.11 \\
\hline $\mathbf{2}$ & $\begin{array}{c}\text { Animal Husbandry+ } \\
\text { Agriculture }\end{array}$ & 21 & 35.00 & 23 & 38.33 & 15 & 25.00 & 59 & 32.78 \\
\hline $\mathbf{3}$ & $\begin{array}{c}\text { Animal Husbandry+ } \\
\text { Agriculture+ other } \\
\text { Total }\end{array}$ & 26 & 43.33 & 19 & 31.67 & 11 & 18.33 & 56 & 31.11 \\
\hline & 60 & 100 & 60 & 100 & 60 & 100 & 180 & 100 \\
\hline
\end{tabular}

$\mathrm{F}=$ frequency, $\%=$ per cent

Table.8 Distribution of respondents on the basis of flock size of goat $(n=180)$

\begin{tabular}{|c|c|c|c|c|c|c|c|c|c|}
\hline \multirow[t]{2}{*}{ S.No. } & \multirow[t]{2}{*}{ Flock size } & \multicolumn{2}{|c|}{ Jodhpur } & \multicolumn{2}{|c|}{ Nagaur } & \multicolumn{2}{|c|}{ Pali } & \multicolumn{2}{|c|}{ Total } \\
\hline & & $\mathbf{F}$ & $\%$ & $\mathbf{F}$ & $\%$ & $\mathbf{F}$ & $\%$ & $\mathbf{F}$ & $\%$ \\
\hline 1 & Small (<15 goats) & 19 & 21.67 & 32 & 53.33 & 12 & 20.00 & 63 & 35.00 \\
\hline 2 & Medium (15-30 goats) & 15 & 25.00 & 13 & 21.67 & 23 & 38.33 & 51 & 28.33 \\
\hline \multirow[t]{3}{*}{3} & Large (>30 goats) & 26 & 43.33 & 15 & 25.00 & 25 & 41.67 & 66 & 36.67 \\
\hline & Total & 60 & 100 & 60 & 100 & 60 & 100 & 180 & 100 \\
\hline & Mean \pm SE & \multicolumn{2}{|c|}{$34.33 \pm 4.86$} & \multicolumn{2}{|c|}{$23.15 \pm 2.42$} & \multicolumn{2}{|c|}{$33.75 \pm 2.80$} & \multicolumn{2}{|c|}{$29.46 \pm 1.68$} \\
\hline
\end{tabular}

$\mathrm{F}=$ frequency, $\%=$ per cent 
Table.9 Distribution of respondents on the basis of cast $(n=180)$

\begin{tabular}{|c|c|c|c|c|c|c|c|c|c|}
\hline S.No & \multirow{2}{*}{ CAST } & \multicolumn{3}{|c|}{ Jodhpur } & \multicolumn{2}{c|}{ Nagaur } & \multicolumn{2}{c|}{ Pali } & \multicolumn{2}{c|}{ Total } \\
\hline & & F & $\mathbf{\%}$ & F & $\mathbf{\%}$ & F & \% & F & $\%$ \\
\hline $\mathbf{1 .}$ & SC & 09 & 15.00 & 07 & 11.67 & 05 & 8.33 & 21 & 11.67 \\
\hline $\mathbf{2 .}$ & ST & 02 & 3.33 & 01 & 1.67 & 01 & 1.67 & 04 & 2.22 \\
\hline $\mathbf{3 .}$ & SBC & 04 & 6.67 & 02 & 3.33 & 37 & 61.67 & 43 & 23.89 \\
\hline $\mathbf{4 .}$ & OBC & 40 & 66.67 & 45 & 75.00 & 16 & 26.66 & 101 & 56.11 \\
\hline $\mathbf{5 .}$ & GEN. & 05 & 8.33 & 05 & 8.33 & 01 & 1.67 & 11 & 6.11 \\
\hline & Total & 60 & 100 & 60 & 100 & 60 & 100 & 180 & 100 \\
\hline
\end{tabular}

$\mathrm{F}=$ frequency, $\%=$ per cent

Table.10 Distribution of respondents on the basis of goat income $(n=180)$

\begin{tabular}{|c|c|c|c|c|c|c|c|c|c|}
\hline \multirow[t]{2}{*}{ S.No. } & \multirow[t]{2}{*}{ Income(₹) } & \multicolumn{2}{|c|}{ Jodhpur } & \multicolumn{2}{|c|}{ Nagaur } & \multicolumn{2}{|c|}{ Pali } & \multicolumn{2}{|c|}{ Total } \\
\hline & & $\mathbf{F}$ & $\%$ & $\mathbf{F}$ & $\%$ & $\mathbf{F}$ & $\%$ & $\mathbf{F}$ & $\%$ \\
\hline 1 & Low $(<30,000)$ & 23 & 38.33 & 21 & 35.00 & 49 & 81.67 & 93 & 51.67 \\
\hline 2 & $\begin{array}{c}\text { Medium }(30,000- \\
60,000)\end{array}$ & 27 & 45.00 & 31 & 51.67 & 09 & 15.00 & 67 & 37.22 \\
\hline 3 & High $(>60,000)$ & 10 & 16.67 & 08 & 13.33 & 02 & 3.33 & 20 & 11.11 \\
\hline & Total & 60 & 100 & 60 & 100 & 60 & 100 & 180 & 100 \\
\hline
\end{tabular}

$\mathrm{F}=$ frequency, $\%=$ per cent

Table.11 Livestock composition of goat owners $(n=180)$

\begin{tabular}{|c|c|c|c|c|c|}
\hline \multirow[t]{2}{*}{ S. No. } & \multirow[t]{2}{*}{ Livestock } & Jodhpur & Nagaur & Pali & \multirow{2}{*}{$\begin{array}{c}\text { Overall } \\
\text { Mean } \pm \text { SE }\end{array}$} \\
\hline & & Mean \pm SE & Mean \pm SE & Mean \pm SE & \\
\hline 1 & Goat & $34.33 \pm 4.86$ & $23.15 \pm 2.42$ & $33.75 \pm 2.80$ & $29.46 \pm 1.68$ \\
\hline 2 & Sheep & $10.1 \pm 1.08$ & $4.51 \pm 0.52$ & $1.95 \pm 0.32$ & $5.52 \pm 0.48$ \\
\hline 3 & Cattle & $2.1 \pm 0.24$ & $2.13 \pm 0.24$ & $1.86 \pm 0.21$ & $2.03 \pm 1.3$ \\
\hline 4 & Buffalo & $1.51 \pm 0.18$ & $1.35 \pm 0.15$ & $0.25 \pm 0.06$ & $1.03 \pm 0.09$ \\
\hline 5 & Horse & $0.11 \pm 0.04$ & $0.28 \pm 0.11$ & $0.31 \pm 0.09$ & $0.14 \pm 0.03$ \\
\hline 6 & Camel & $0.35 \pm 0.14$ & $0.23 \pm 0.10$ & $0.58 \pm 0.10$ & $0.38 \pm 0.07$ \\
\hline
\end{tabular}

$\mathrm{SE}=$ standard error

The data recorded in table-10 showed that majority $(51.67 \%)$ of the respondents had low level of income while 37.22 per cent had medium level of income and remaining11.11 per cent respondents had high level of income from goats rearing practices in the study area.

These findings were similar to Mordia, A. (2017) and Gameti, R.K. (2018).
Distribution of respondents on the basis of livestock composition

The survey shows that respondents in the study area had maximum number of goats, compared to other livestock. The overall average goats per household in the study area were $29.46 \pm 1.68$. The average holdings of sheep, cattle, buffalo, horse, camel were 
$5.52 \pm 0.48,2.03 \pm 1.3,2.03 \pm 1.3,1.03 \pm 0.09$, $0.14 \pm 0.03$ and $0.38 \pm 0.07$, respectively in the surveyed area (Table-10 and Figure 4.10), a finding similar to the report of Mordia, A. (2017) and Gameti, R.K. (2018).

The study revealed that majority of goat owners were had that the majority $(65.55 \%)$ of the total respondents were middle age group followed by young 19.45 per cent and old age group15.00 per cent It was observed that majority of the respondents education level were illiterate $(63.89 \%)$, respondents had large size families $(41.11 \%)$, living joint type family $(81.67 \%)$, male headed goat owners $(96.67 \%)$ and small land holders $(65 \%)$.

Majority of goat owners (36.11\%) animal husbandry as main occupation. The maximum goat owners of the study area from OBC $(56.11 \%)$. showed that majority $(51.67 \%)$ of the respondents had low level of income while 37.22 per cent had medium level of income and remaining11.11 per cent respondents had high level of income from goats rearing practices in the study area.

\section{References}

AHD, (2012). Animal husbandry department, Rajasthan, 19th Livestock census Rajasthan-2012, animalhusbandry.rajasthan.gov.in./ livestock census aspx.

Bhatia, J., Pandey, U.K. and Suhag, K.S., (2005): Economic analysis of sheep and goat rearing in rain fed region of Haryana, India. Indian Journal of Animal Science,75(12): 1423-1432.

Gameti, R.K. (2018): Studies on Goat Management Practices of Tribal in Dungarpur District of Rajasthan M.V.Sc. thesis submitted to RAJUVAS. Gebreyesus, G., Haile, A. and Dessie, T., (2014): Ethno-veterinary knowledge and practices of issa-somali pastoralists around dire dawa, eastern Ethiopia. International Journal of Research and Reviews in Pharmacy and Applied science, 4(1): 910-921.

Jayashree, R., Jayashankar, M.R., Nagaraja, C.S., Satyanarayana, K. and Isloor, S.(2014):Goat rearing practices in Southern Karnataka. International Journal of Science, Environment,3(4): 1328-1335.

Koli, R.T. and Koli, S.R., (2016): Study of relationship between personal, situational, psychological and socioeconomical characteristics with adoption of goat farming technology by the goat keepers.Research Journal of Animal Husbandry and Dairy Science,7(1): 11-15.

Kumar, R. (2017): Information Seeking Behaviour of tribal livestock owners of Sirohi district of Rajasthan. M.V.Sc. thesis submitted to RAJUVAS.

Mishra, A., (Smt.)Mishra, A. and Jabbar, M.F., (2012): A Motivation and Innovation Profile of Tribal Goat Production System in Pakur District of Jharkhand State.Indian Research Journal ofExtension Education special issue, 1: 326-329.

Mordia, A. (2017): Goat management practices among livestock owners of Chittorgarh district of Rajasthan. M.V.Sc. thesis submitted to RAJUVAS.

Nipane, S.F., Basunathe, V.K., Bankar, S.S., Seth, P., Singh, N. and Singh, N.K. (2016): Socio-economic status of goat keepers in Bhandara district of Maharashtra state.International Journal of Science, Environment and Technology, 5(5):3615-3622.

Sabapara, G.P., Sorthiya, L.M. and Kharadi, V.B., (2016):Constraints in goat husbandry practices by goat owners in Navsari district of Gujarat.International Journal of Agriculture Science \& 
Veterinary Medicine, 2(3): 31-36.

Sharma, M.C., (2005): Genetic investigation of body weight and Morphometry traits of Sirohi goats in the field. Ph.D. Thesis submitted to MPUAT, Udaipur (Raj.).

Sharma, M.C., Pathodiya, O.P., Jingar, S.C. and Gaur, M., (2007): A study on socioeconomic status of goat rearers and adoption of management practices. The Indian Journal of Small Ruminants, 13(1): 75-83.
Singh, M.K. and Rai, B. (2006): Barbari breed of goat: Reasons of dilution in its home tract. Indian Journal of Animal Sciences, 76(9): 716-719.

Tanwar, P.S., Vaishanava, C.S. and Sharma, V. (2008).A study on socioeconomic aspects of goat keepers and Management practices prevailed in the tribal areaof Udaipur district of Rajasthan. Indian Journal of Animal Research,42(1): 71-74.

\section{How to cite this article:}

Shripal Siyak, M. L. Gurjar, M. C. Sharma, Rohitash Kumar and Dushyant Dev Bhal. 2020. Socio- Economic Characteristic of Goat Keepers in Marwar Region of Rajasthan State, India. Int.J.Curr.Microbiol.App.Sci. 9(06): 2795-2803. doi: https://doi.org/10.20546/ijcmas.2020.906.338 